\title{
Reserach автісів: Heterosis studies in sweet sorghum [Sorghum bicolor (L.) Moench] hybrids for green fodder yield and its attributing traits
}

\section{T. SOUJANYA, T. SHASHIKALA, A. V. UMAKANTH AND VASEEM}

Article Chronicle: Received :

17.07.2017;

Accepted :

01.08 .2017

KEY WoRDS: Sweet sorghum, Heterosis, Fodder yield

Author for correspondence :

\section{T. SOUJANYA}

Department of Genetics and Plant Breeding, College of Agriculture, Professor Jayashankar Telangana State Agricultural University, Rajendranagar, HYDERABAD (TELANGANA) INDIA

Email: thotasoujanya66 @gmail.com
SUMMARY : An experiment was conducted to study the magnitude of heterosis in forty eight $\mathrm{F}_{1}$ hybrids of sweet sorghum [Sorghum bicolor (L.) Moench] for single-cut green fodder yield and its components. The hybrids and their parents (4 lines and 12 testers) were evaluated in Randomized Block Design with three replications. Observations were recorded on seventeen characters viz., early vigour, days to 50 per cent flowering, plant height, number of leaves per plant, leaf length, leaf breadth, number of nodes per plant, internodal length, stem girth, leaf to stem ratio, sugar brix, green fodder yield, dry matter content, dry fodder yield, ADF, NDF and crude protein. Heterotic studies revealed the presence of significant heterosis over best check in many cross combinations. The hybrid 185A x RSSV466 exhibited significant heterosis in desirable direction for green fodder yield, its component characters and quality traits. Therefore, this cross could be utilized for commercial cultivation after sufficient testing in All India trials.

How to cite this article : Soujanya, T., Shashikala, T., Umakanth, A.V. and Vaseem (2017). Heterosis studies in sweet sorghum [Sorghum bicolor (L.) Moench] hybrids for green fodder yield and its attributing traits. Agric. Update, 12(TECHSEAR-6) : 1604-1611; DOI: 10.15740/HAS/AU/12. TECHSEAR(6)2017/1604-1611. 